\title{
Nutritional intake and overall diet quality of female soccer players before the competition period
}

\author{
Ingestão nutricional e qualidade global da \\ dieta de jogadoras de futebol antes \\ do período de competição
}

Daniel dos SANTOS 1

Jacqueline Queiroz da SILVEIRA ${ }^{1}$

Thais Borges CESAR ${ }^{1}$

\section{A B S T R A C T}

\section{Objective}

To assess the dietary intake and overall diet quality of female soccer players before the competitive games.

\section{Methods}

This descriptive and cross-sectional study included 21 women aged $20.8 \pm 4.5$ years from a professional soccer team. Their nutritional status and dietary adequacy during the training period, before competition season, were assessed. Dietary intake was assessed by three 24-hour recalls, one food frequency questionnaire, and the Healthy Eating Index, an overall diet quality index based on food group intake.

\section{Results}

The athletes have shown proper nutritional status, but a diet deficient in energy due largely to low carbohydrate intake. On the other hand, the intakes of protein, fatty acids, and sodium were above the recommended intakes, even for athletes. Diet quality assessment by the Healthy Eating Index - 2010 resulted in a mean score of 54.6 points of a maximum of 100, indicating a need of improving the overall diet quality.

\section{Conclusion}

The study found that the dietary patterns of female football players were both quantitatively and qualitatively inappropriate. A nutritional intervention is indicated to improve diet quality, with the inclusion of various foods, such as whole grains, fruits, vegetables, dairy products, and better protein quality, along with a reduction in saturated fats, sodium, and added sugar.

Keywords: Nutritional assessment. Healthy Eating Index. Soccer. Women.

\footnotetext{
1 Universidade Estadual Paulista Júlio de Mesquita Filho, Faculdade de Ciências Farmacêuticas, Departamento de Alimentos e Nutrição. Rod. Araraquara-Jaú, km 1, 14802-901, Araraquara, SP, Brasil. Correspondência para/Correspondence to: TB CESAR. E-mail: <tcesar@fcfar.unesp.br>

Article based on the doctoral dissertation of D SANTOS, intitled "Estado nutricional, perfil bioquímico e estresse oxidativo em jogadoras de futebol pré e pós o período competitivo". Universidade Estadual Paulista Júlio de Mesquita Filho; 2012.
} 


\section{R E S U M O}

\section{Objetivo}

Avaliar a ingestão alimentar e a qualidade nutricional global da dieta de jogadoras de futebol antes dos jogos competitivos.

\section{Métodos}

Estudo descritivo transversal realizado com 21 mulheres, de 20,8 44,5 anos de idade, de uma equipe de futebol profissional. Elas foram avaliadas em relação ao seu estado nutricional e adequação da dieta durante o período de treinamento, antes da temporada de competição. A ingestão alimentar foi avaliada por três recordatórios de 24 horas, um questionário de frequência alimentar e pelo Índice de Alimentação Saudável (2010), um indice de qualidade global da dieta baseada no consumo de grupos de alimentos.

\section{Resultados}

Verificou-se que as atletas apresentavam estado nutricional adequado, mas tinham uma dieta deficiente em energia devido, em grande parte, à ingestão insuficiente de carboidratos. Por outro lado, o consumo de proteínas, ácidos gordos e de sódio estavam acima da recomendação, mesmo para atletas. A avaliação da qualidade da dieta pelo Índice de Alimentação Saudável (2010) mostrou uma pontuação média de 54,6 de 100, exibindo a necessidade de melhoria da qualidade da dieta.

\section{Conclusão}

O estudo mostrou padrões alimentares inadequados, tanto quantitativa como qualitativamente, em jogadoras de futebol. A intervenção nutricional é indicada para melhorar a qualidade da dieta com a inclusão de vários itens alimentares, como cereais integrais, frutas, legumes, produtos lácteos e melhor qualidade de proteínas, acompanhado de redução de gorduras saturadas, sódio e açúcar.

Palavras-chave: Avaliação nutricional. Índice de Alimentação Saudável. Futebol. Mulheres.

\section{INTRODUCTION}

Few studies have investigated the food habits of soccer players and their relationship with performance in this sport. In female athletes nutrient imbalance and low energy intake are the main nutritional factors that reduce body weight and disturb in the endocrine system regarding calcium and iron ${ }^{1}$. In this sense an adequate intake of nutrients and energy is recommended to maintain muscle glycogen reserves and optimize performance in soccer. Therefore, assessment of dietary intake is fundamental for the sport in order to establish adequate intake standards, after taking into consideration the specificities of the group, such as age, sex, body composition, energy expenditure during training and competition, and nutritional deficiencies, to improve performance and establish specific dietary guidelines for each modality ${ }^{2}$.

Previous studies assessing the nutritional intake of female soccer players have used only quantitative methods to measure nutrient intake ${ }^{3-6}$ with regard to the recommendations of the American College of Sports Medicine and American Dietetic Association? ${ }^{7}$. However, the literature lacks an evaluation of the overall diet quality of soccer players, which takes into consideration global aspects of a healthy diet, using, for example, the Healthy Eating Index (HEl). The HEI can detect the absent, excessive, or balanced intake of the main food groups, which can be useful to guide real changes in food choices $^{8-10}$. Both approaches, i.e., the nutritional evaluation and HEI-2010 will provide a wider analysis based on the quantity and quality of the eating pattern regarding a healthy diet, and therefore, contribute to improve dietary behaviors and physical performance, and still protect the health of young footballers ${ }^{9}$.

The HEl has been used to evaluate the diet of the general population in nutritional interventions and to supervise the diet of specific people. The method consists of comparing food intake with 
the main recommendations of the Dietary Guidelines for Americans, United States Department of Agriculture - 200510, which is based on the Dietary Reference Intakes (DRIs) ${ }^{11}$. Diet quality is characterized by a defined food group amount, expressed as g/1000 kcal, focusing on energy density. Unhealthy foods are also evaluated, emphasizing the negative aspects of diets that must be corrected. The approach of this method provides a measure of the overall diet quality, based on the consumption of food groups that contribute to energy and main nutrient intakes, not just the quantity of the foods consumed, leading to better eating patterns $s^{9,10}$.

An important goal of this study was to understand the nutritional and eating pattern of female soccer players before competitive games, and therefore, to optimize performance and health in the activities involved in the competitive period. In the future, information on diet quality can be used to design and implement practical dietary and nutrition education programs for athletes. In this group the intake of energy, macronutrients, and food groups, and diet quality were studied comprehensively ${ }^{11}$ and assessed by HEl-2010'. The study also aimed at identifying possible deficiencies or excesses in their eating patterns, and to make specific dietary recommendations for this phase of training, in order to improve the athletic performance and the health of these soccer players.

\section{METHODS}

Thirty elite female soccer players from a professional athletic association were enrolled in this study. The inclusion criterion was being a soccer player for at least two years, while the exclusion criterion was regular use of nutritional supplements, such as vitamins, minerals, or both. The final group of selected soccer players $(n=21)$ aged $20.8 \pm 4.5$ years consisted of sides $(n=5)$; midfielders ( $n=7)$; forwards $(n=3)$; full-backs $(n=5)$, and goalkeeper $(n=1)$ (Table 1). They were lodged at the training center house, where they had their daily meals. They were informed of the experimental procedures and all volunteers signed consent statements, which were previously approved by Universidade de Franca Research Ethics Committee $n^{\circ}$ 0074/10.

This descriptive and cross-sectional study focused on sports nutrition. It was conducted before the competition period of the Female Championship organized by Paulista Soccer Federation in São Paulo, Brazil. During the study period, the athletes had routine training from Monday to Friday, 3 hours daily (morning and afternoon), with a half day of recovery in the middle of the week. In the first week before the competitive season (March to July), their anthropometric variables were measured (body weight, height, skinfold thicknesses) and the dietary-nutritional estimates (24-hour recall) were recorded.

Table 1. Metabolic Equivalent of Task (MET) according to the type, frequency, and duration of the weekly training sessions of female soccer athletes. Franca (SP), Brazil, 2012.

\begin{tabular}{llccc}
\hline Type of training & \multicolumn{1}{c}{ Training protocol } & Frequency work & Duration minutes & MET \\
\hline Strength & Training with weights & 2 & 60 & 6 \\
& Race drive & 1 & 15 & 15 \\
Strength and velocity & Velocity and agility with balls & 1 & 30 & 7 \\
Relax & Pool-water aerobics & 1 & 60 & 4 \\
Technical exercises & With ball & 1 & 60 & 7 \\
Velocity resistance & Running & 1 & 60 & 7 \\
Tactical training & Strategy position in field & 1 & 60 & 7 \\
& Training game & 1 & 90 & 10 \\
Finalizations with balls & Faults, corners, crossing, and penalties & 1 & 60 & 7 \\
Game & Official game & 1 & 90 & 10 \\
\hline
\end{tabular}


The exercise training protocol included several types of weekly exercises that consisted of exercises of strength, speed, speed endurance, and relaxation, tactical training by mechanisms of perception, analysis, decision and interaction with the ball with teammates and opponents and, finally the official games. A detailed description of the frequency, duration, and energy expenditure for the exercises is shown in Table 1. The athletes were divided into five tactical positions: sides, midfielders, forwards, full-backs, and goalkeeper for the study of the physical characteristics and total energy expenditure per position (Table 2).

Energy expenditure was estimated by the Metabolic Equivalent of Task (MET) for each type of training, identified in the Compendium of Physical Activity ${ }^{12}$, where one MET corresponds to a resting oxygen uptake of $3.5 \mathrm{~mL}^{\mathrm{kg}} \mathrm{kg}^{-1} \cdot \mathrm{min}^{-1}$. The Energy Expenditure of Exercise (EEE) was estimated by the formula ${ }^{12}$ below, and is shown in Table 2:

EEE $(k c a l)=$ MET of exercise $x$ body weight $(\mathrm{kg}) \times$ duration of exercise $(h)$

Where ${ }^{11}$ :

$\leq 18 y=[135.5-30.8 x$ age $(y)+10 x$ weight $(\mathrm{kg})+934 \mathrm{x}$ height $(\mathrm{cm})]$ $\geq 18 y=[354-6.9 x$ age $(y)+9.4 x$ weight $(\mathrm{kg})+726 x$ height $(\mathrm{cm})]$

\section{Anthropometric and dietary evaluation}

Weight was measured by a calibrated mechanical scale (Filizola ${ }^{\circledR}$, Filizola S/A Pesagem e Automação, São Paulo, Brazil), and height, by a stadiometer. Body mass index (BMI) was given by the relationship weight/height ${ }^{2}$. Body composition was evaluated by four skinfold thicknesses (triceps, suprailiac, abdominal, and thigh) obtained by averaging three consecutive measurements of each fold with the Compass Lange ${ }^{\circledR}$ (Beta Technology Incorporated, United States). Finally, body density ${ }^{13}$ and body fat percentage ${ }^{14}$ were calculated.

Daily food and beverage intakes were determined by three 24-hour recalls of two weekdays and one weekend day. Food intake was expressed as portion size, brand of processed foods, sugar and oil intake, and preparation method. Energy intake was estimated from the macronutrient intake, where $1 \mathrm{~g}$ of protein or carbohydrate equals $4 \mathrm{kcal}$ and $1 \mathrm{~g}$ of fat equals $9 \mathrm{kcal}$. The dietary nutritional contents were analyzed by the Diet Software Pro ${ }^{\circledR}$ (Nutrition Software, Viçosa, MG, Brazil version 4.0), and the nutritional requirements were estimated according to the DRIs ${ }^{11}$. A food frequency questionnaire was also administered, containing the following food groups: fruits, vegetables,

Table 2. Anthropometric characteristics and energy expenditure of the female soccer players according to playing position. Franca (SP), Brazil, 2012

\begin{tabular}{|c|c|c|c|c|c|c|c|c|c|c|c|}
\hline \multirow{3}{*}{ Variables } & \multicolumn{9}{|c|}{ Team position } & \multirow{2}{*}{\multicolumn{2}{|c|}{ All players $(n=21)$}} \\
\hline & \multicolumn{2}{|c|}{ Sides $(n=5)$} & \multicolumn{2}{|c|}{ Midfielders $(n=7)$} & \multicolumn{2}{|c|}{ Forwards $(n=3)$} & \multicolumn{2}{|c|}{ Full-backs $(n=5)$} & \multirow{2}{*}{$\begin{array}{l}\text { Goalkeeper } \\
\qquad(n=1)\end{array}$} & & \\
\hline & $M$ & DP & $M$ & $\mathrm{DP}$ & M & $\mathrm{DP}$ & M & DP & & M & DP \\
\hline Age (years) & 22.6 & 2.2 & 22.4 & 6.7 & 17.3 & 1.5 & 18.6 & 2.1 & 23.0 & 20.9 & 4.5 \\
\hline Weight (kg) & 52.5 & 4.8 & 56.4 & 7.9 & 57.7 & 5.6 & 59.1 & 2.2 & 68.6 & 56.9 & 6.3 \\
\hline BMI $\left(\mathrm{kg} / \mathrm{m}^{2}\right)$ & 21.7 & 3.5 & 22.2 & 1.7 & 21.4 & 1.7 & 21.5 & 0.9 & 23.7 & 21.9 & 2.0 \\
\hline Body fat (\%) & 13.5 & 2.1 & 15.2 & 2.1 & 15.6 & 4.4 & 14.7 & 0.5 & 16.2 & 14.6 & 2.3 \\
\hline Muscle mass (\%) & 86.6 & 2.1 & 84.8 & 2.1 & 84.4 & 4.4 & 85.9 & 1.4 & 83.8 & 85.4 & 2.3 \\
\hline REE (kcal) & 1823.0 & 59.0 & 1799.0 & 178.0 & 1813.0 & 101.0 & 1830.0 & 154.0 & 2071.0 & 1827.0 & 139.0 \\
\hline $\mathrm{EEE}$ (kcal) & 807.0 & 74.0 & 866.0 & 121.0 & 888.0 & 87.0 & 909.0 & 32.0 & 1055.0 & 874.0 & 98.0 \\
\hline TEE (kcal) & 2630.0 & 117.0 & 2665.0 & 288.0 & 2701.0 & 126.0 & 2739.0 & 165.0 & 3126.0 & 2701.0 & 214.0 \\
\hline
\end{tabular}

Note: REE + EEE Comparisons of each variable (by line) among team positions were not statistically different according to one-way analysis of variance (ANOVA) ( $p>0.05)$

REE: Resting Energy Expenditure; EEE: Energy Expenditure of Exercise; TEE: Total Energy Expenditure; BMI: Body Mass Index. 
grains, milk and dairy products, meat and legumes, oil, sodium, alcohol, and added sugar, based on the HEl-20109.

\section{Assessment of the food groups and overall diet quality}

Overall diet quality is given by adding the scores of 11 food components, varying from 0 to 100 points. A score of 80-100 indicates a good diet, a score of 51-80 reflects the need of improving diet quality, and a score $<51$ reflects a poor $\operatorname{diet}^{9}$. Components scoring 0 to 5 are: total fruits, whole fruits, total vegetables, greens and beans, total protein foods, and seafood/plant proteins. Components scoring 0 to 10 are: whole grains, dairy, fatty acids, refined grains, and sodium. A final component scoring 0 to 20 is described as "empty calories", coming from solid fats, alcohol, and added sugar. The overall diet quality is estimated by averaging the daily intake of each component and comparing it with the equivalent maximum value $(\mathrm{g} / 1000 \mathrm{kcal} / \mathrm{d})$ and score $(0$ to 100$)$ of the HEl food component.

Limitations of the $\mathrm{HEl}$ method include its restricted use, indicated only for active and adult individuals ${ }^{9}$. Also, the dietary assessment methods, as the 24-hour recall and food frequency questionnaire, are subject to reporting bias because of self-reported data and the different sources of food components ${ }^{15}$.

\section{Statistical analyses}

Data were expressed as mean \pm standard deviation. The distribution of the variables was analyzed by the Kolmogorov-Smirnov test. Variables with normal distribution were analyzed by the Student's $t$-test (intake versus recommended) or one-way Analysis of Variance (ANOVA) (anthropometric variables and energy expenditure by playing position). Statistical tests were performed by the Statistical Package for the Social Sciences (SPSS Inc., Chicago, Illinois, United
States) version 21, and the statistical significance level was set at $p<0.05$.

\section{RES ULTS}

Weekly training sessions according to exercise type, frequency, and duration, expressed as Metabolic Equivalent of Task (MET), are shown in Table 1. The Resting Energy Expenditure (REE) and the Total Energy Expenditure (TEE) were described for each tactical position and for the whole team in Table 2.

The minimum and maximum values for athletes' characteristics were 15-34 years, 47.3-66.6 kg body weight, 10.7-20.7\% body fat, and BMI of $8.2-27.3 \mathrm{~kg} / \mathrm{m}^{2}$. Despite the variations between the minimum and maximum values, no significant differences were found for any of the anthropometric variables by playing position (Table 2). Moreover, the mean energy expenditure during exercise (EEE) was about $32.0 \%$ of the mean total energy expenditure (TEE), which represents an activity of moderate-high intensity.

Daily macronutrient intake (Table 3) corresponded to a mean of $2306 \mathrm{kcal} / \mathrm{d}$, which covers only $85.0 \%$ of the daily energy requirement. Nonetheless, macronutrient intake was balanced, comprising $54.0 \%$ carbohydrates, $19.7 \%$ proteins, and $26.3 \%$ lipids. According to food group distribution, the most consumed carbohydrates were rice (7 days/week), bread and crackers (5 days/week) and pasta (2.2 days/week), with little intake of candy, soft drinks, and sugar. However, the most consumed protein sources were from animals, such as red meat, poultry, and meat products, with little milk and dairy product intakes. The intake of dietary cholesterol was slightly high, $24.0 \%$ above the recommended maximum, due to the intake of meat and meat products, such as sausages and ham. Fiber intake was low, but sodium intake was $50.0 \%$ above the recommended intake.

The overall diet quality of female soccer players, evaluated by the $\mathrm{HEI}-2010^{9}$, is presented 
in Table 4. Consumption of total fruits and whole fruits reached 46 and $61 \%$ of the standard score, showing a lower consumption of these food items than the recommended by the food guide ${ }^{10}$, with scores of 2.3 and 3.0, respectively. The intake of total vegetables and greens, and beans were approximately $40 \%$ and $156 \%$ of the standard score, reaching 2 and 5 points, respectively. The main legume of the diet was beans, consumed at a frequency of 7 days/week. However, whole grains (unrefined) were not consumed, which resulted in a score of zero for this component.

With regard to dairy products, consumption was only $30 \%$ of the recommended, obtaining a score of 3.9. The evaluation of total intake of protein foods showed that the athletes had exceeded the recommendation, so this component had a score of 5 . Seafood and plant proteins achieved a score of 3.2 due to an intake equal to $64 \%$ of the HEl standard. Fatty acids

Table 3. Daily energy, macronutrient, and sodium intakes of female soccer players compared with the recommended values. Franca (SP), Brazil, 2012.

\begin{tabular}{|c|c|c|c|c|}
\hline \multirow{2}{*}{ Nutrients/d } & \multicolumn{2}{|c|}{ Intake } & \multirow{2}{*}{ Recommended } & \multirow{2}{*}{ Diagnosis } \\
\hline & M & SD & & \\
\hline Energy $^{11}$ (kcal) & 2306 & $405^{*}$ & $2701 \pm 214$ & Below \\
\hline Carbohydrates $7.11(\%)$ & 54.0 & 5.1 & $45-65$ & Appropriate \\
\hline Carbohydrates ${ }^{7,11}(\mathrm{~g} / \mathrm{kg})$ & 5.5 & 0.9 & $6-10$ & Below \\
\hline Proteins $7,11(\%)$ & 19.7 & 3.3 & $10-35$ & Appropriate \\
\hline Proteins $\mathrm{s}^{7,11}$ (g/kg) & 2.0 & 0.5 & $1.2-1.7$ & Above \\
\hline Lipids ${ }^{11}(\%)$ & 26.3 & 5.6 & $20-35$ & Appropriate \\
\hline Saturated fat ${ }^{16}(\%)$ & 10.1 & 2.3 & $<10$ & Above \\
\hline Fiber $^{11}(\mathrm{~g})$ & 16.5 & 3.3 & 37.8 & Below \\
\hline Sodium ${ }^{11}(\mathrm{~g})$ & 2.3 & 0.6 & 1.5 & Above \\
\hline
\end{tabular}

Note: ${ }^{p} \leq 0.05$. Statistical comparison (t-test) was between the actual and recommended energy/nutrient intakes. M: Mean; SD: Standard Deviation.

Table 4. Diet quality of the female soccer players before the competitive period according to the Healthy Eating Index (HEI) Franca (SP), Brazil, 2012

\begin{tabular}{|c|c|c|c|c|c|c|c|}
\hline \multirow{3}{*}{ HEI components } & \multicolumn{3}{|c|}{ Intake } & \multicolumn{4}{|c|}{ HEl parameters } \\
\hline & \multicolumn{2}{|c|}{$g / d$} & \multirow{2}{*}{$\mathrm{g} / 1000 \mathrm{kcal} / \mathrm{d}$} & \multirow{2}{*}{$\begin{array}{l}\text { Maximum value, } \\
\text { g/1000 kcal/d }\end{array}$} & \multirow{2}{*}{ Maximum points } & \multicolumn{2}{|c|}{ Score } \\
\hline & $\mathrm{M}$ & SD & & & & $\mathrm{M}$ & SD \\
\hline \multicolumn{8}{|l|}{ Fruits (g) } \\
\hline Total & 86.0 & 31.8 & 37.0 & 80.0 & 5 & 2.3 & 0.8 \\
\hline Whole & 56.0 & 17.4 & 24.5 & 40.0 & 5 & 3.0 & 0.9 \\
\hline \multicolumn{8}{|l|}{ Vegetables (g) } \\
\hline Total & 75.7 & 32.7 & 32.8 & 82.5 & 5 & 2.0 & 0.9 \\
\hline Greens and beans & 72.0 & 5.1 & 31.2 & 20.0 & 5 & 5.0 & 1.6 \\
\hline Whole grains (g) & 0.0 & - & 0.0 & 45.0 & 10 & 0 & - \\
\hline Dairy products (g) & 292.0 & 104.0 & 126.0 & 318.0 & 10 & 3.9 & 1.4 \\
\hline Total protein foods (g) & 379.0 & 147.0 & 164.0 & 67.0 & 5 & 5.0 & 1.9 \\
\hline Seafood/plant proteins (g) & 31.7 & 1.3 & 13.7 & 21.3 & 5 & 3.2 & 1.6 \\
\hline Fatty acids (ratio) & 0.5 & & 0.2 & 2.5 & 10 & 2.0 & 0.1 \\
\hline Refined grains (g) & 182.0 & 9.1 & 79.1 & $\leq 51.0$ & 10 & 6.5 & 0.4 \\
\hline Sodium (g) & 2.3 & 0.6 & 0.9 & $\leq 1.1$ & 10 & 10.0 & 1.0 \\
\hline Empty calories (\%) & 28.3 & 4.8 & - & $\leq 20.0$ & 20 & 11.7 & 2.0 \\
\hline Total & & & & & 100 & 54.6 & 2.8 \\
\hline
\end{tabular}

Note: M: Mean; SD: Standard Deviation. 
ratio, that favors the high intake of polyunsaturated fats from sources such as fish, nuts, and others, was $86 \%$ lower than the recommended, showing very low consumption of these items, which scored 2. On the contrary, refined grains scored 6.5 , with consumption of $155 \%$ of the recommended.

Sodium consumption was 39\% above the established standard ${ }^{16}$, and scored 4 . The calories coming from empty calories of solid fats, alcohol, and added sugar exceeded the recommended by $41 \%$, reaching 11.7 points due to the high consumption of added sugar, drink mixes, and soft drinks. Finally, the overall diet quality of the female players, given by the sum of the scores of all HEl-2010 components, totaled $54.6 \pm 0.7$ of 100 (Table 4), meaning that the diet needs improvement to achieve the recommended standards and maintain players' health.

\section{DISCUSSION}

This study verified low dietary energy intake by female soccer players shortly before the competitive season as a consequence of insufficient carbohydrate intake. On the other hand, protein intake exceeded the recommended intake for athletes but not enough to cover their energy requirement. Overall diet quality evaluation by the $\mathrm{HEI}-2010^{9}$ showed the need of improving their diet by adding more whole grains, fruits, vegetables, milk, and dairy products, and less saturated fats, sodium, and added sugar.

The players had different tactical functions during the training (sides, mid-fielders, forwards, full-backs, and goalkeeper), but their energy expenditures for the workouts were not statistically different and their BMI, body fat, and lean body mass did not differ (Table 2). These results confirm a previous study where footballers had similar body composition and performance, regardless of tactical position ${ }^{17}$. Furthermore, REE, EEE, and TEE did not differ by tactical position (Table 2), suggesting that workout intensity was equal for all athletes. The mean TEE was $2700 \mathrm{kcal}$, suggesting high-energy intake compared with non-athletic women with moderate physical activity ${ }^{17}$.

Nutritional analyses showed that the athletes' energy intake was $40.8 \mathrm{kcal} / \mathrm{kg}$ of body weight/day, a higher energy intake than those reported by similar studies, which found energy intakes of 34 and $31 \mathrm{kcal} / \mathrm{kg} /$ day, respectively ${ }^{2,18}$. Although our athletes consumed a greater amount of energy by unit of body weight, the daily energy intake $(2306 \mathrm{kcal} / \mathrm{d})$ in relation to the calculated requirement $(2701 \mathrm{kcal} / \mathrm{d})$ was deficient by $395 \mathrm{kcal} /$ day. This energy deficit could compromise athletic performance, since carbohydrates account for $60 \%$ of the total energy expenditure during a soccer game ${ }^{19}$. Also, a gradual weight loss that seems minor at the time of measurement could be important over time. Besides, negative energy balance can have an impact on recovery rates, training adaptation, cognitive functions, and immune system, interfering with the women's ability to train and compete ${ }^{20}$.

The American Dietetic Association ${ }^{7}$ advocates that 60 to $70 \%$ of athletes' total energy intake must come from carbohydrates. Considering this recommendation, the women's total carbohydrate intake was much lower than the recommended $(54 \% \pm 5.1 p<0.05)$. Other studies have also reported insufficient carbohydrate intake by female athletes, ranging from 48 to $55 \%$ of the total energy requirement $\mathrm{t}^{5,6,21}$. The recommended carbohydrate intake for all athletes is 6 to $10 \mathrm{~g} / \mathrm{kg} / \mathrm{d}^{7}$ to maintain glycogen synthesis and sufficient muscle and hepatic energy reserves. The study athletes consumed $5.5 \mathrm{~g} / \mathrm{kg} /$ day, which suggests poor sports performance as it compromises energy supply and consequently, leads to early fatigue.

The recommended protein intake for athletes is based on the need of tissue maintenance and addition, and protein muscle repair, and as an alternative energy source ${ }^{7}$. The study protein intake $(2.0 \pm 0.54 \mathrm{~g} / \mathrm{kg} /$ day $)$ far exceeded the amount recommended by the DRIs $(0.8 \mathrm{~g} / \mathrm{kg} / \mathrm{day}))^{11}$ and by the ADA's ${ }^{7}$ for athletes (1.2 to $1.7 \mathrm{~g} / \mathrm{kg} /$ day). Other studies with soccer 
athletes ${ }^{5,6,22}$ also reported protein intakes above the DRIs, but within the ADA recommendations. According to Campbell et al. ${ }^{23}$, other factors must be considered, besides the amount of protein, such as protein quality, energy and carbohydrate intakes, and exercise type and intensity. Therefore, the protein requirement of high-level athletes can exceed the normal upper limit of recommendation $(1.7 \mathrm{~g} / \mathrm{kg} /$ day) due to higher branched-chain amino acid oxidation, which in turn increases the protein requirement.

For intermittent exercises, like soccer, basketball, martial arts, and others, the recommended protein intake ranges from 1.4 to $1.7 \mathrm{~g} / \mathrm{kg} /$ day $^{24,25}$. The International Society of Sports Nutrition recommends a protein intake of 1.4 to $2.0 \mathrm{~g} / \mathrm{kg} /$ day for people who exercise, and for those who practice resistance exercises, the intake must stay closer to the lower limit. For intermittent exercise practice, like soccer, the athletes must consume the intermediate level $(1.7 \mathrm{~g} / \mathrm{kg} /$ day $)$, and those who practice strength/ power exercises should consume the upper recommended limit ( $2 \mathrm{~g} / \mathrm{kg} /$ day). Therefore, it is probable that the surplus protein intake by the study athletes is used by their intermediate-level metabolism to cover energy intake deficit.

The quantity of total lipids in the players' diet (26\% of the daily energy intake) was in accordance with the AMDR (20-35\% of the daily energy intake), although approaching the upper DRI limit ${ }^{11}$. Similar results (30\% of the daily energy intake) were also found by others studies on female soccer players ${ }^{2,18}$, but lower than that reported by Clark et al. ${ }^{5}$. Although total fat intake is appropriate, monounsaturated and polyunsaturated fat intakes were low. These fats come mostly from foods like fish, nuts, and grains. The main source of saturated fat in the study women was soy oil, preferentially used for food preparation. Saturated fat intake exceeded 10\% of the daily energy intake, which is not appropriate according to the $\mathrm{HEI}-2010$ (7\% of the daily energy intake). Martin et al. ${ }^{18}$ found the same in female soccer athletes and advised that excessive saturated fat intake is deleterious for healthy players.

The next step was to evaluate total diet quality by the HEI-2010'. The study women's intake of total and whole fruits was low, reflected by the lower scores of those food groups (0.94 servings/day). Bacardí-Gascón et al. ${ }^{26}$ found that $60 \%$ of female karate players consumed fewer than two servings of fruit a day ( 1.5 servings/day). According to Watson et al. ${ }^{27}$, regular consumption of fruits and vegetables plays an important role in organ protection against oxidative stress and its effects on performance. The fruit intake of the study women was limited to orange intake 3 times/week. This represents a great risk for muscles and tissues in general due to the inadequate intake of antioxidant compounds that must be present in the regular diet, especially of people under high physiological stress, such as athletes during training and competition ${ }^{28}$.

The study athletes' total vegetable intake was lower than $50 \%$ of the recommended intake, according to the HEI. Their mean daily intake was 1.2 servings/day, which was insufficient to meet their requirements of water-soluble vitamins, carotenoids, minerals, and dietary fibers. Almeida \& Soares ${ }^{29}$ found a similar result in female volleyball players, who ingested only $50 \%$ of the adequate folate intake. According to the International Association of Athletics Federations ${ }^{30}$, a varied and adequate intake of legumes and vegetables is essential for maintaining athletes' health and optimizing their performance. The main and sometimes only legume in the players' diet was beans, but they were consumed 6 to 7 times/week. So, associated with the meats' group, there was a very significant consumption of these food items, exceeding $100 \%$ of the recommended intakes.

The study footballers did not consume whole grains, but they had a large intake of refined grains, exceeding 35\% of the maximum recommended. Regular consumption of whole grains can help to supply dietary magnesium, vitamin E, calcium, and potassium, which are 
nutrients required by muscle activity ${ }^{31}$. The lack of whole grain intake also decreased dietary fiber intake, because whole grains are also good sources of fiber. The study women had inadequate fiber intake, equivalent to $66 \%$ of the recommended intake, which was also found by Caccialanza et al. . $^{32}$ in male soccer players. In both studies, low fiber intake was caused by low frequency of fruit, vegetable, and whole grain intakes.

The intakes of milk and dairy products were $40 \%$ lower than those recommended by the $\mathrm{HEl}$, with low intake of high quality milk protein and specifically, of highly bioavailable calcium. Milk and dairy products consumption is essential for the formation of bones and maintenance of bone mineral density in female athletes, and inadequate calcium intake increases the risk of osteoporosis as they age $\mathrm{e}^{33}$.

On the other hand, the sodium intake of these female athletes was high, which was also observed by Martin et al. ${ }^{18}$, who reported an intake of $2300 \mathrm{mg} /$ day, exceeding $100 \%$ of the maximum recommended sodium intake (1500 mg/day) (DRI 2006) ${ }^{11}$. The excessive amount of this electrolyte in the diet is mostly due to the overuse of salt and commercially processed products or fast foods with high sodium content. High sodium intake is strongly related to health problems, such as hypertension, stroke, cardiovascular disease, and obesity ${ }^{34}$.

Finally, the last item of the overall diet quality evaluation was foods that contain "empty calories", such as solid fats, alcohol, and added sugar. Their intakes were slightly above the recommended values as they should not provide more than $20 \%$ of the daily energy intake. The main contribution came from the added sugars (4.2 times/week), followed by alcohol (beer + wine + distilled drinks) consumed 0.8 times/week, and solid fats consumed 3.5 times/week.

The mean diet quality score of these soccer players (54.6 \pm 0.7$)$ was lower than the maximum possible score (100), showing that the diet needs improvement in many aspects. For instance, the athletes must increase their intakes of fruits $(47 \%)$, vegetables $(64 \%)$, whole grains $(100 \%)$, milk and dairy products (61\%), and fish, nuts, and seeds (80\%). On the other hand, saturated fat $(-31 \%)$, and sodium $(-60 \%)$ intakes must be reduced.

\section{CONCLUSION}

This study found that the overall diet quality of the female soccer players was inappropriate, if compared with the nutritional guidelines, due to low energy and carbohydrate intakes, and high protein and sodium intakes. Also according to the HEI-2010, their diet needs improvement because of the low intakes of fruits, vegetables, and dairy products, and high intakes of animal protein and refined grains. Therefore, it will be necessary to invest in the athletes' nutritional education and inform them about healthy food habits, and intervene in the diet planning and elaboration ${ }^{35}$ to correct and control the dietary imbalances and achieve a nutritionally healthy improvement and consequently, better sports performance.

\section{CONTRIBUTORS}

TB CESAR and D SANTOS were responsible for the study design. D SANTOS and JQ SILVEIRA carried out the data collection and statistical analyses. D SANTOS, JQ SILVEIRA and TB CESAR drafted the manuscript. All authors read and approved the manuscript.

\section{ACKNOWLEDGEMENT}

The authors would like to thank the athletes for the committed participation. Moreover, we thank Veronica Cook for writing assistance.

\section{REFERENCES}

1. Beals K, Manore MM. Nutritional considerations for the female athlete. In: Spurway N, MacLaren D, 
editors. Advances in sport and exercise science series: Nutrition and sport. Philadelphia (PA): Elsevier; 2007. p.185-204.

2. Mullinix MC, Jonnalagadda SS, Rosenbloom CA, Thompson WR, Kicklighter JR. Dietary intake of female U.S. soccer players. Nutr Res. 2003, 23(5):585-93.

3. Tek NA, Yildiran H, Akbulut G, Bilici S, Koksal E, Gezmen KM, et al. Evaluation of dietary quality of adolescents using Healthy Eating Index. Nutr Res Pract. 2011; 5(4):322-8.

4. Freedman LS, Guenther PM, Krebs-Smith SM, Kott PS. A population's mean Healthy Eating Index - 2005 scores are best estimated by the score of the population ratio when one 24-hour recall is available. J Nutr. 2008; 138(9):1725-9.

5. Clark M, Reed DB, Crouse SF, Armstrong RB. Pre and post-season dietary intake, body composition, and performance indices of NCAA division I female soccer players. Int J Sport Nutr Exerc Metab. 2003; 13(3):303-19.

6. Scott D, Chisnall PJ, Todd MK. Dietary analysis of English female soccer players. In: Reilly T, Williams $\mathrm{M}$, editors. Science and soccer. London: Routledge; 2003. p.245-50.

7. American College of Sports Medicine, American Dietetic Association, Dietitians of Canada. Position of the American Dietetic Association, Dietitians of Canada, and the American College of Sports: Nutrition and athletic performance. J Am Diet Assoc. 2009; 109(3):509-27.

8. Kennedy ET, Ohls J, Carlson S, Fleming K. The Healthy Eating Index: Design and applications. J Am Diet Assoc. 1995; 95(10):1103-8.

9. Guenther PM, Casavale KO, Reedy J, Kirkpatrick SI, Hiza HA, Kuczynski KJ, et al. Update of the Healthy Eating Index: HEl-2010. J Acad Nutr Diet. 2013; 113(4):569-80. http://dx.doi.org/10.1016/j. jand.2012.12.016

10. United States Department of Agriculture. Department of Health and Human Services and Department of Agriculture. Dietary Guidelines for Americans. $6^{\text {th }}$ ed. Washington (DC): U.S. Government Printing Office; 2005. [cited 2015 June 10]. Available from: http://www.healthierus.gove/ dietaryguidelines

11. Institute of Medicine. Dietary reference intakes for energy, carbohydrate, fiber, fat, fatty acids, cholesterol, protein, and amino acids. Washington (DC): National Academy of Sciences; 2006.

12. Ainsworth BE, Haskell WL, Herrmann SD, Meckes N, Bassett DR Jr, Tudor-Locke C, et al. Compendium of Physical Activities: A second update of codes and MET values. Med Sci Sports Exerc. 2011; 43(8):1575-81.
13. Jackson AS, Pollock ML, Ward A. Generalized equations for predicting body density of women. Med Sci Sports Exerc. 1980; 12(3):175-82.

14. Lohman TG, Roche AF, Martorell R. Anthropometric standardization reference manual. Champaign (III): Human Kinetics Books; 1988.

15. Britten P, Marcoe K, Yamini S, Davis C. Development of food intake patterns for the My Pyramid Food Guidance System. J Nutr Educ Behav. 2006; 38(Suppl. 6):S78-92.

16. Sociedade Brasileira de Cardiologia; Sociedade Brasileira de Hipertensão; Sociedade Brasileira de Nefrologia. [VI Diretrizes brasileiras de hipertensão]. Arq Bras Cardiol. 2010; 95(Supl. 1):1-51. Erratum in: Arq Bras Cardiol. 2010; 95(4):553.

17. Zoran M, Sporis G, Nebojsa T. Differences in body composite and physical match performance in female soccer players according to team position. J Hum Sport Exerc. 2012; 7(Proc1):S67-72.

18. Martin L, Lambeth A, Scott D. Nutritional practices of national female soccer players: Analysis and recommendations. J Sports Sci Med. 2006; 5(1):130-7.

19. McArdle WD, Katch Fl, Katch VL. Sport and exercise nutrition. $3^{\text {th }}$ ed. Philadelphia (PA): Lippincott, Williams and Wilkins; 2008.

20. Prado WL, Botero JP, Guerra RLF, Rodrigues CL, Cuvello LC, Dâmaso AR. Perfil antropométrico e ingestão de macronutrientes em atletas profissionais brasileiros de futebol, de acordo com suas posições. Rev Bras Med Esporte. 2006; 12(2):61-5.

21. Gravina L, Ruiz F, Diaz E, Lekue JA, Badiola A, Irazusta J, et al. Influence of nutrient intake on antioxidant capacity, muscle damage and white blood cell count in female soccer players. J Int Soc Sports Nutr. 2012; 9(1):32.

22. Maughan RJ, Gleeson M. The biochemical bases of performance in sports. Rio de Janeiro: Guanabara Koogan; 2004.

23. Campbell B, Kreider RB, Ziegenfuss T, La Bounty P, Roberts M, Burke D, et al. International Society of Sports Nutrition position stand: Protein and exercise. J Inter Soc Sport Nutr. 2007; 4(8)1-7.

24. García-Rovés PM, García-Zapico P, Ángeles MP, Iglesias-Gutiérrez E. Nutrient intake and food habits of soccer players: Analyzing the correlates of eating practice. Nutrients. 2014; 6(7)2697-717. http://dx. doi.org/10.3390/nu6072697

25. Devlin JT, Williams C. Final consensus statement: Foods, nutrition and sports performance. J Sports Sci. 1991; 9(Suppl.):14-6.

26. Bacardí-Gascón M, Llata MEL, Santibañez-González MO, Campo-Garcia JR. Low consumption of milk, 
fruit and vegetables, and reduced calcium, iron and zinc intake in female teenage athletes and Mexican karate competitors. Rev Biomed. 2005; 16(2):71-7.

27. Watson TA, MacDonald-Wicks LK, Garg ML. Oxidative stress and antioxidants in athletes undertaking regular exercise training. Int J Sport Nutr Exerc Metab. 2003; 15(2):131-46.

28. Deminice R, Degiovanni, GC, Garlipp-Picchi MR, Nóbrega MT, Teixeira M, Jordão AA. Evolução de biomarcadores de estresse oxidativo e relação com a performance competitiva em dois momentos da temporada de treinamento de natação. Rev Bras Med Esporte. 2009; 15(4):277-81.

29. Almeida TA, Soares EA. Nutritional and anthropometric profile of adolescent volleyball athletes. Rev Bras Med Esporte, 2003; 9(4):198-203.

30. International Association of Athletics Federation. Nutrition for athletics: A practical guide to eating and drinking for health and performance in track and field. Monaco: International Association of Athletics Federation; 2007 [cited 2015 Apr 10]. Available from: http://www.iaaf.org/mm/document/ imported/42817.pdf
31. O'Neil CE, Nicklas TA, Zanovec M, Cho SS, Kleinman R. Consumption of whole grains is associated with improved diet quality and nutrient intake in children and adolescents: The National Health and Nutrition Examination Survey 1999-2004. Public Health Nutr. 2011; 14(2):347-55.

32. Caccialanza R, Cameletti B, Cavallaro G. Nutritional intake of young Italian high-level soccer players: Under-reporting is the essential outcome. J Sports Sci Med. 2007; 6(4):538-42.

33. Maughan RJ, Shirreffs SM. Nutrition and hydration concerns of the female football player. Br J Sports Med. 2007; 41(Suppl. 1):i60-3.

34. World Health Organization. Diet, nutrition and the prevention of chronic diseases: Report of a joint WHO/FAO expert consultation. Technical Report Series, n 916. Geneve: WHO; 2003.

35. Abood DA, Black DR, Birnbaum RD. Nutrition education intervention for college female athletes. J Nutr Educ Behav. 2004; 36(3):135-7.

Received: June 22, 2015 Final version: April 7, 2016 Approved: April 27, 2016 
